\title{
Non-Imprinted In Prader-Willi/Angelman Syndrome Region Protein 1
}

National Cancer Institute

\section{Source}

National Cancer Institute. Non-Imprinted In Prader-WilliAngelman Syndrome Region

Protein 1. NCI Thesaurus. Code C75740.

Non-imprinted in Prader-Willi/Ang elman syndrome region protein 1 (329 aa, $35 \mathrm{kDa}$ ) is encoded by the human NIPA1 gene. This protein may be involved in the development of the nervous system. 